\title{
Notes on a Lower Jaw of Palorchestes Azael.
}

By Charles W. De Vis, B.A.

It may perhaps be allowed that a small accession to our scanty knowledge of Australian palæosteology may be useful, even though it merely tend to increase our acquaintance with known forms, and define their taxonomic relations. By the kindness of one of the Trustees of the Queensland Museum, W. H. Miskin, Esq., an opportunity is given of describing the lower dentition and form of jaw in a very young Palorchestes Azael, (Owen), and of noting thereby some features of interest.. The fossil was obtained by Mr. Miskin from well-sinkers who met with it at a depth of 70 feet near St. Ruth, on the Darling Downs. In the original condition of the specimen the mandibles were displaced at the symphysis forwards and upwards, and in this position reconnected by the cementation of the mineralising agent, calcium carbonate. By the more unlucky accident of pressure acting upon the anterior third of the jaw transversely to its long axis, both rami have lost their natural flexure. The left being certainly much straighterthe right probably somewhat more strongly and abruptly curved in wards at the symphysis, than in the normal condition. On clearing away adhering matrix, the whole of the teeth, with the exception of the left premolar, which has been carried away with a piece of the bone, and the second molar of the same side, which is fractured, were found in excellent preservation. The combined length of the series $\mathrm{d}^{4} \mathrm{~m}^{\mathrm{x}} \mathrm{m}^{2}$, is exactly as in the portion of an adult jaw figured by Professor Owen (Foss. Mant. Aust., Pl. Cvi., fig. 1). The shallowness of the jaw below the growing molars, characteristic of the young macropod, is a conspicuous feature of the present fossil - its depth beneath the second molar being little more than half that of the adult mandible, and about two-thirds of the depth which it attains below the premolar. The evidence derived from this deeping of the mandible from behind forward, tending to show that Palorchestes was more nearly allied to the kangaroo proper, than to the Protemnodontidæ, is of some weight, since, though not confirmed, it is not belied by 
the structure of the premolar. This tooth has a form peculiarly its own, differing equally from the subtrenchant bitubercular tooth of the former, and the long fluted, chisel-like tooth of the latter. It is eight lines long and three lines broad, of a semioval form, with its outer surface convex and sloping rapidly downwards. On this aspect it has two shallow indents at about equal thirds of its length, the posterior being the deeper and broader of the two. On its inner surface it rises vertically from the socket into a median lobe, separated from the fore and hind angles by indents, of which the anterior is long and shallow, the posterior shorter and deeper, each of them being separated from its anticlinal indent, by a short median ridge. The apex of the mid lobe is worn down sufficiently to expose an inwardly directed loop of dentine, and the general shape of the tooth being reniform with the pelvis turned inward a little more attrition would extend the dentine loop into the form of an open double curve. The prebasal ridge of $d^{4}$ is developed on its outer two-thirds only, and is connected with the anterior lobe by a minute link. The anterior lobe, like all the other lobes of the teeth in place, has on its anterior aspect a broad and shallow indent. The median link is well developed and, rising from the middle of the posterior surface of the fore lobe, subsides on the outer angle of the anterior side of the hinder lobe. The post-basal ridge is equally broad on either side of the mid link-in other respects it is as described in the worn tooth by Prof. Owen. The same must be said of the other characters of this tooth-nor can anything be added of importance to Prof. Owen's description of $\mathrm{m}^{1}$ itself. All the teeth in place $\mathrm{p}^{3} \mathrm{~d}^{4}$ and $\mathrm{m}^{1}$ are equally worn, in each there is a narrow line of dentine exposed by the abrasion of the enamel. The enamel of $\mathrm{m}^{2}$ is of course intact, the hinder lobe of the tooth having but lately risen fairly above the gum. The incisor is remarkable for the unusual expansion of its base, at the incisive outlet it measures twelve and a-half lines, a width exceeding its whole length by more than one-fifth. Its inner edge, in opposition to that of its fellow is straight, its outer has a parabolic curve from the outer angle of the socket to the lip of the inner edge. The internal or posterior surface is at the inner edge strongly concave, 
the concavity gradually decreases towards the outer edge, but on the posterior surface of the outer edge itself is a strong fold (formed of a revolution of the edge backwards) running upwards from the base and subsiding as it reaches the cutting edge. The outer or fore surface of the tooth is curved longitudinally and transversely, and is covered with shallow confluent excavations. The diastema is long, being nearly equal in length to the space occupied by the three anterior grinders. It descends from the premolar with a gentle curve, and rises with a slighter curve to the incisive outlet. Commencing about four lines in front of the vertical from the premolar, the symphysis presents a long moderately deep and nearly horizontal syndesmotic surface, with longitudinal rugæ. The union of the mandibles through much broader and firmer than in Macropus, is far inferior in those respects to that of Procoptodon, and corresponds rather with that of Sthenurus. The same observation applies to the direction in which the incisor is implanted. The dental foramen is midway between the vertical from the premolar and the incisive outlet, and is six and a-half times below the mediasternal ridge, in both respects differing much from its position in Macropus. A longitudinal groove commences at the vertical from the fore lobe of $\mathrm{d}^{4}$ and gradually deepening as it runs backwards, separates the lower border of the mandible from the sub-alveolar convexity, which increases rapidly below the permanent molars. The groove ends rather abruptly at the origin of the inflected angle. The postalveolar angle is prominent, the outer alveolar groove, narrow and shelving. On the outer side anteriorly, the alveolar ridge is well separated by compressure from the subalveolar convexity beneath the premolar, and is continued backwards from the diastema in a straight slope to the middle of $\mathrm{m}^{1}$. The subalveolar convexity subsides considerably beneath $\mathrm{d}^{4}$, but again increasing, is at its greatest at the base of the coronoid process. This process appears to rise at a comparatively low angle. On the same parallel with the base of the coronoid process, is the commencement of the ridge bounding the outer crotaphyte fossa posteriorly-but the lower brim of that fossa does not present itself between the two points as it does in Macropus. 


\section{AUSTRALIAN AND POLYNESIAN LAND AND MARINE MOLLUSCA,}

We have in this jaw a diastema unlike that of any known macropod, but having its greatest similitude in Sthenurus. It is in the latter genus again that we find some approach to the greatly dilated incisor in the mandible before us. It has already been observed that the symphysis is that of Sthenurus rather than of Macropus on the one hand, or of the more aberrant macropod, Procoptodon, on the other. Concomitant with these indications of alliance with Sthenurus, we find however, a premolar departing from all others of the family. It seems, therefore, reasonable to surmise that Palorchestes was on the whole a true saltigrade of the macropodal type, and that the point of divergence whence its differentiation commenced, was Sthenurus or some form closely allied to it. The use to which the determination of such relationship may be put, is best known to those who have to deal with the disconnected bones of the numerous extinct species of kangaroos; without its guidance their identification, always doubtful in some degree, becomes the most unsatisfactory guesswork.

Synonymy of Australian and Polynesian land and Marine Mollusca.

By J. Brazier, C.M.Z.S., \&c., \&c.

1. Patella aculeata.

Patella aculeata, Reeve, Conch. Icon., pl. 32, sp. 90. squamifera, Reeve, Coc. cit, sp. 94. aculeata, Angas, Proc. Zool. Soc., p. 221, 1867. squamifera, Angas, loc. cit., p. 221, 1867. aculeata, Tenison-Woods, Proc. Roy.Soc.Tas., p. 22, 1877, Hab.-Port Jackson near the Heads, and outside from the Clarence River on the north, to Twofold Bay on south; it is also found in Tasmania.

I have had some hundreds of specimens of the so-called species squamifera, but I can only identify them with aculeata. The very rough sculptured variety is of very common occurence at tho Old 


\section{$2 \mathrm{BHL}$ Biodiversity Heritage Library}

De Vis, Charles Walter. 1883. "Notes on a lower jaw of Palorchestes Azael." Proceedings of the Linnean Society of New South Wales 8, 221-224. https://doi.org/10.5962/bhl.part.28651.

View This Item Online: https://www.biodiversitylibrary.org/item/30993

DOI: https://doi.org/10.5962/bhl.part.28651

Permalink: https://www.biodiversitylibrary.org/partpdf/28651

\section{Holding Institution}

MBLWHOI Library

\section{Sponsored by}

MBLWHOI Library

\section{Copyright \& Reuse}

Copyright Status: NOT_IN_COPYRIGHT

This document was created from content at the Biodiversity Heritage Library, the world's largest open access digital library for biodiversity literature and archives. Visit BHL at https://www.biodiversitylibrary.org. 